\title{
SISTEM INFORMASI AKTA KEPENDUDUKAN BERBASIS WEB PADA DINAS KEPENDUDUKAN DAN PENCATATAN SIPIL KABUPATEN KAMPAR RIAU
}

\author{
${ }^{1}$ Tengku Khairil Ahsyar, ${ }^{2}$ Syaifullah, ${ }^{3}$ Abu Bakar \\ ${ }^{1,2,3}$ Program Studi Sistem Informasi, Fakultas Sains dan Teknologi \\ Universitas Islam Negeri Sultan Syarif Kasim Riau \\ Jl. HR Soebrantas, KM. 18.5, No. 155, Simpang Baru, Pekanbaru, Indonesia, 28293. \\ Email: 'tengkukhairil@uin-suska.ac.id, ${ }^{2}$ syaifullah@uin-suska.ac.id, ${ }^{3}$ abubakar.trtk@gmail.com
}

\begin{abstract}
ABSTRAK
Dinas Kependudukan dan Pencatatan Sipil Kabupaten Kampar merupakan unsur pelaksana tugas daerah yang dipimpin oleh seorang kepala dinas dan bertanggung jawab kepada bupati melalui sekretaris daerah. Salah satu tugas pokok Disdukcapil adalah menyelenggarakan pelayanan dalam bidang kependudukan dan pencatatan sipil dan melaksanakan pelayanan administrasi dalam bidang kependudukan, akta kelahiran, kematian, perkawinan, perceraian, perubahan nama dan pengakuan anak. Namun dalam prosesnya masih terdapat kekurangan-kekurangan yaitu tidak adanya kepastian kapan akta selesai, informasi persyaratan yang masih kurang dan jarak yang jauh bagi masyarakat yang tinggal jauh dari kantor Disdukcapil. Fokus penelitian ini adalah untuk membuat sistem informasi akta kependudukan berbasis web. Metode pengembangan sistem yang digunakan dalam penelitian ini adalah waterfall dengan 5 tahapan yaitu requirements analysis and defenition, system and software design, implementation and unit testing, integration and system testing, dan operation and maintenance yang dibatasi hanya sampai pada tahap integration and system testing. Berdasarkan hasil pengujian sistem menggunakan UAT menunjukkan bahwa tingkat penerimaan terhadap sistem informasi akta kependudukan adalah sebesar $100 \%$. Dengan adanya sistem informasi akta kependudukan ini masyarakat dapat melihat informasi persyaratan, melakukan pendaftaran dan melihat status permohonan melalui sistem secara online.
\end{abstract}

Kata kunci: dinas kependudukan dan pencatata sipil kabupaten kampar, sistem informasi akta kependudukan, waterfall.

\section{A. PENDAHULUAN}

Kabupaten Kampar merupakan salah satu kabupaten yang ada di Provinsi Riau, Indonesia. Kabupaten Kampar yang beribukota di Bangkinang, dikenal juga dengan julukan serambi Mekkah atau Bumi Sarimadu di Provinsi Riau. Kabupaten Kampar memiliki luas lebih kurang 27.908,32 km², terletak antara $1^{\circ} 00^{\prime} 40^{\prime \prime}$ Lintang Utara sampai $0^{\circ}$ $27^{\prime} 00^{\prime \prime}$ Lintang Selatan dan $100^{\circ} 28^{\prime} 30^{\prime \prime}-101^{\circ} 14^{\prime} 30^{\prime \prime}$ Bujur Timur. Kabupaten Kampar memiliki 21 Kecamatan yaitu Kampar Kiri, Kampar Kiri Hulu, Kampar Kiri Hilir, Gunung Sahilan, Kampar Kiri Tengah, XIII Koto Kampar, Koto Kampar Hulu, Kuok, Salo, Tapung, Tapung Hulu, Tapung Hilir, Bangkinang Kota, Bangkinang, Kampar, Kampar Timur, Rumbio Jaya, Kampar Utara, Tambang, Siak Hulu, Perhentian Raja [1].

Jumlah Penduduk Kabupaten Kampar berdasarkan proyeksi penduduk tahun 2015 sebanyak 793.005 jiwa yang terdiri atas 407.228 jiwa penduduk laki-laki dan 385.777 jiwa penduduk perempuan. Dibandingkan dengan proyeksi jumlah penduduk tahun 2014, penduduk Kabupaten Kampar tahun 2015 mengalami pertumbuhan sebesar $2,57 \%$ dengan masing-masing persentase pertumbuhan penduduk laki-laki sebesar 2,55\% dan penduduk perempuan sebesar 2,58\% [2]. Dalam menangani bidang kependudukan, Kabupaten Kampar dibantu oleh Dinas Kependudukan dan
Pencatatan Sipil Kabupaten Kampar. Berdasarkan Peraturan Daerah Kabupaten Kampar Nomor 6 Tahun 2008, dalam melaksanakan tugas pokok, Disdukcapil mempunyai fungsi diantaranya menyelenggarakan pelayanan dalam bidang kependudukan dan catatan sipil, menyusun program kebijakan dalam bidang kependudukan dan catatan sipil, dan melaksanakan pelayanan administrasi dalam bidang kependudukan, akta kelahiran, kematian, perkawinan, perceraian, perubahan nama dan pengakuan anak.

Disdukcapil Kabupaten Kampar terus berupaya untuk meningkatkan kualitas pelayanannya terhadap masyarakat, sesuai dengan fungsi dan tugasnya yaitu melayani pengurusan pendaftaran penduduk dan pencatatan sipil. Layanan pendaftaran penduduk adalah kegiatan penelitian dan pencatatan data penduduk akibat terjadinya kelahiran, kematian, perpindahan, kedatangan, perubahan status kependudukan dan mutasi data. Berdasarkan data dari Disdukcapil Kabupaten Kampar, penerbitan akta kelahiran dari tahun 20122015 adalah sebanyak 99.459 akta, penerbitan akta perkawinan sebanyak 5.269 akta, dan penerbitan akta kematian sebanyak 1.236 akta, serta akta perceraian sebanyak 5 akta. Penerbitan akta kematian mengalami peningkatan dalam 4 tahun terakhir. 
Proses pembuatan akta kependudukan di Kabupaten Kampar memang harus dilakukan di Kantor Disdukcapil Kabupaten Kampar, sehingga mengharuskan masyarakat untuk datang langsung ke Kantor Disdukcapil. Masih ada masyarakat yang sudah terlanjur datang harus kembali lagi keesokan harinya dikarenakan berkas persyaratan yang tidak lengkap. Berdasarkan data wawancara yang telah dilakukan, bahwa seringkali masyarakat yang ingin mengurus akta kelahiran tidak membawa fotokopi buku nikah dengan alasan tidak tahu dan tidak memiliki buku nikah karena nikah sirih, sehingga terpaksa berkas permohonannya di-pending dan diminta untuk melengkapi. Disamping itu waktu pengurusan akta kependudukan di Disdukcapil Kampar juga terbilang lama. Meskipun di dalam Standar Operasional Pelayanan (SOP) disebutkan bahwa pengurusan akta kependudukan maksimal lama pengurusannya adalah 14 hari, namun yang terjadi bisa saja proses pengurusan akta kependudukan baru selesai dalam waktu 3 minggu atau lebih.

Selain itu, masyarakat juga tidak mendapatkan informasi jika akta kependudukan tersebut telah selesai, sehingga masyarakat harus sering melakukan pengecekan di Disdukcapil Kabupaten Kampar. Ini menimbulkan masalah lain yaitu untuk datang ke kantor Disdukcapil tentu memerlukan biaya transportasi yang harus ditanggung oleh masyarakat, apalagi oleh masyarakat yang jarak tempat tinggalnya jauh dari Kantor Disdukcapil Kabupaten Kampar. Keadaan tersebut sering dimanfaatkan oleh oknum tertentu (calo) untuk mendapatkan keuntungan dengan menawarkan pengurusan akta kependudukan yang lebih cepat dengan bayaran tertentu. Selain dapat menggangu proses pelayanan, ulah oknum ini tentu bertentangan dengan peraturan pemerintah yang menggratiskan biaya pengurusan akta.

Tujuan dari penelitian ini untuk membangun sistem informasi akta kependudukan berbasis web pada Disdukcapil Kabupaten Kampar. Sistem yang akan dibangun diharapkan dapat mengatasi permasalahan yang sering terjadi dalam pengurusan akta kependudukan dan memacu minat masyarakat untuk melakukan pengurusan akta kependudukan secepatnya.

Pembangunan sistem informasi akta kependudukan ini menggunakan metode waterfall yang merupakan metode klasik yang bersifat sistematis, berurutan dalam membangun software [3][9]. Dalam waterfall terdapat lima fase yaitu requirements analysis and defenition, system and software desing, implementation and unit testing, integration and system testing, dan operation and maintenance [4]. Teknik perancangan yang digunakan adalah Object Oriented Analysis Desain (OOAD) dengan menggunakan tool Unified Modeling Language (UML). Diagram yang digunakan dalam UML yaitu Use Case, Class
Diagram, Activity Diagram, Sequnce Diagram. Penerapan Metode OOAD sebelumnya sudah pernah dilakukan pada beberapa penelitian dan berhasil mempermudah dalam proses pengembangan sistem [11][12]. Sedangkan Pengujian sistem menggunakan User Acceptance Test (UAT).

Suripto dan Triyono (2014) meneliti tentang Pembangunan Sistem Informasi Akta Kelahiran pada Dinas Kependudukan dan Pencatatan Sipil Sragen. Hasil dari penelitiannya menunjukan sistem akta kelahiran memberi kemudahan dalam mencatat, mendokumentasikan, dan penyajian laporan bagi peristiwa kelahiran [5]. Dalam penelitian Suarti dan Sujianto (2014) yang meneliti tentang Reformasi Birokrasi Pengurusan Akta Kelahiran di Dinas Kependudukan dan Pencatatan Sipil Kabupaten Kampar, diketahui bahwa masih ada masyarakat yang belum tahu persyaratan pengurusan akta kelahiran dikarenakan kurangnya sosialisasi dari pemerintah [6].

Berdasarkan dari masalah di atas maka penelitian ini fokus untuk membangun sistem informasi akta kependudukan berbasis web pada Dinas Kependudukan dan Pencatatan Sipil Kabupaten Kampar.

\section{B. LANDASAN TEORI}

\section{B.1. Akta Kependudukan}

Menurut Kamus Besar Bahasa Indonesia (KBBI) [10], akta adalah surat tanda bukti berisi pernyataan (keterangan, pengakuan, keputusan, dan sebagainya) tentang peristiwa hukum yang dibuat menurut peraturan yang berlaku, disaksikan, dibuat, dan disahkan oleh pejabat resmi. Akta adalah suatu tulisan yang memang dengan sengaja dibuat untuk dijadikan bukti tentang suatu peristiwa dan ditandatangani pihak yang membuatnya [7].

Akta kelahiran adalah bukti sah mengenai status dan peristiwa kelahiran seseorang yang dikeluarkan oleh Disdukcapil. Akta kematian adalah suatu akta yang dibuat dan diterbitkan oleh Disdukcapil yang membuktikan secara pasti tentang kematian seseorang. Bagi mereka yang melakukan perkawinan menurut agama Islam, pencatatan dilakukan di Kantor Urusan Agama (KUA), sedangkan bagi yang beragama Katholik, Kristen, Budha, Hindu, pencatatan itu dilakukan di Kantor Catatan Sipil setelah kedua mempelai melakukan pernikahan menurut agamanya masing-masing. Akta perceraian adalah bukti sahnya perceraian yang diperlukan sebagai dasar legalitas putusnya ikatan perkawinan dan perubahan status sebagai janda atau duda cerai hidup.

\section{B.2. Pendekatan Berorientasi Objek}

Pendekatan berorientasi objek merupakan cara berfikir baru serta berlogika dalam menghadapi masalah-masalah yang akan diatasi dengan bantuan komputer [8]. OOAD mencakup analisis dan desain 
sebuah sistem dengan pendekatan objek, yaitu OOA dan OOD. OOA adalah tahapan perangkat lunak dengan menentukan spesifikasi sistem dan mengidentifikasi kelas-kelas serta hubungannya satu terhadap yang lain [8]. OOD adalah merancang kelas-kelas yang teridentifikasi selama tahap analisis dan antarmuka (user interface) [8][9].

\section{B.3. Waterfall}

Waterfall (Gambar 1) merupakan salah satu model proses perangkat lunak yang mengambil kegiatan proses dasar seperti spesifikasi, pengembangan, validasi dan evolusi dengan mempresentasikannya sebagai fase-fase proses yang berbeda seperti analisis defenisi persyaratan, perancangan perangkat lunak, implementasi dan pengujian unit, integrasi dan pengujian sistem, operasi dan pemeliharaan [3][9].

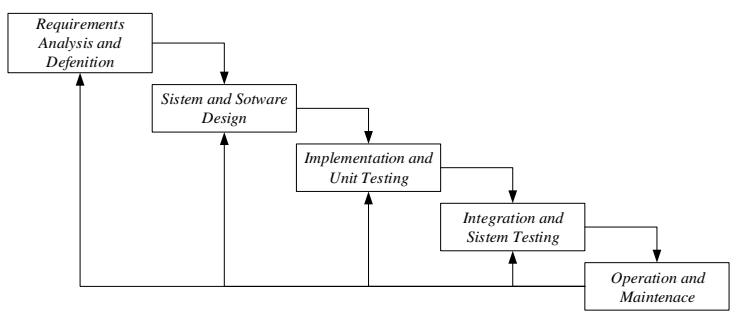

Gambar 1. Model Waterfall Sommerville

\section{METODOLOGI PENELITIAN}

Berikut ini merupakan proses dan tahapantahapan yang dilalui dalam penelitian ini yang dapat dilihat pada Gambar 2.

\section{C.1. Tahap Perencanaan}

Tahap perencanaan merupakan tahap awal dalam penelitian ini, kegiatan yang dilakukan dalam tahap ini yaitu: penentuan topik, penentuan objek penelitian, perumusan masalah, penentuan judul dan penentuan tujuan.

\section{C.2. Tahap Pengumpulan Data} yaitu:

Teknik pengumpulan data yang digunakan

1) Observasi

Pengamatan langsung proses pembuatan akta pada Dinas Kependudukan dan Pencatatan Sipil Kabupaten Kampar.

2) Wawancara

Melakukan wawancara kepada kabid capil bapak Asril, SE, M.Si

3) Studi pustaka.

Berupa jurnal pernelitian terdahulu, arsip dinas kependudukan serta buku-buku referensi untuk menambah data pendukung dalam penelitian.

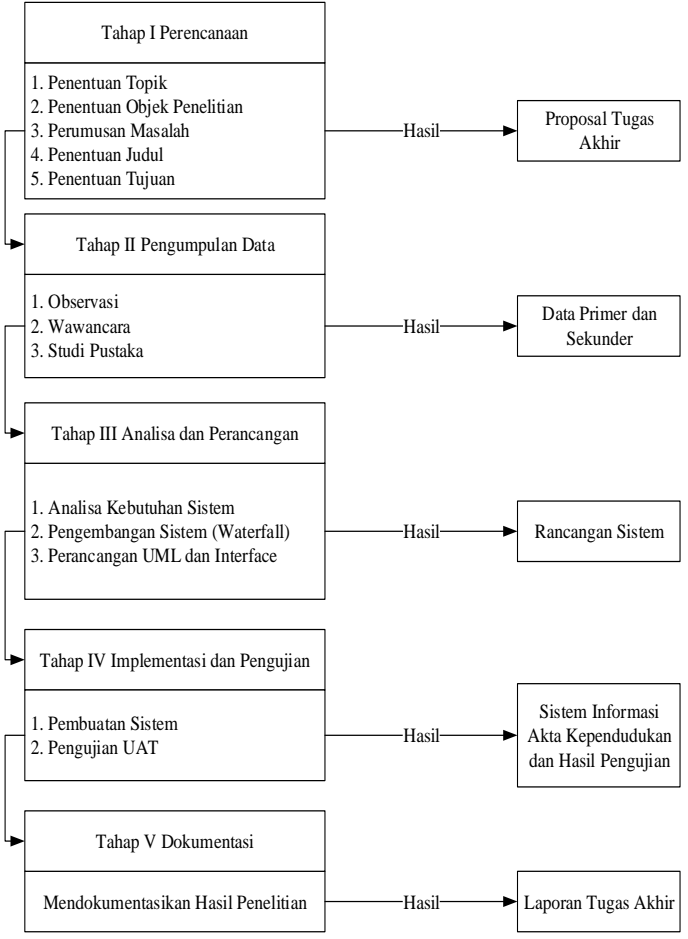

Gambar 2. Metodologi Penelitian

\section{C.3. Tahap Analisa dan Perancangan}

Dalam tahap ini dilakukan kegiatan sebagai berikut: analisa kebutuhan sistem, metode pengembangan sistem, perancangan UML dan interface.

1) Analisa Kebutuhan Sistem

2) Metode Pengembangan Sistem

Metode pengembangan sistem yang digunakan dalam penelitian ini adalah waterfall [4], dimana dibatasi hanya sampai pada tahap Integrasi dan pengujian sistem.

3) Perancangan UML dan Interface

Tahap perancangan ini yaitu merancang database yang akan digunakan dengan menggunakan MySql serta interface sistem yang akan dibangun nantinya. Alat bantu UML yang digunakan dalam melakukan perancangan diantaranya Use Case, Class Diagram, Activity Diagram, dan Sequence Diagram.

\section{C.4. Tahap Implementasi dan Pengujia}

Tahap ini dilakukan pengujian sistem dengan menggunakan metode pengujian UAT. Hal ini bertujuan untuk melakukan pengujian terhadap sistem yang telah dikembangkan kepada pengguna sistem atau user sebagai verifikasi akhir untuk mendapatkan konfirmasi bahwa sistem yang dikembangkan telah memenuhi persyaratan yang disepakati.

Adapun butir pertanyaan dalam pengujian UAT ini adalah sebagai berikut: 
1) Apakah tampilan Sistem Informasi Akta Kependudukan berbasis web ini sudah bagus dan menarik?

2) Apakah Sistem Informasi Akta Kependudukan berbasis web ini mudah digunakan (user friendly)?

3) Apakah menu-menu pada Sistem Informasi Akta Kependudukan berbasis web ini mudah dipahami atau dipelajari?

4) Apakah Sistem Informasi Akta Kependudukan ini dapat membantu dan memecahkan permasalahan-permasalahan anda dalam pembuatan akta?

5) Ketika sistem di jalankan apakah ada terjadi kesalahan/error?

\section{C.5. Tahap Dokumentasi}

Pada tahapan terakhir, dilakukan proses pendokumentasian seluruh kegiatan yang dilakukan pada penelitian ini, mulai dari proses pendahuluan, perencanaan, pengumpulan data, analisa dan perancangan sistem, dan implementasi dan pengujian sistem. Hasil dari dokumentasi ini adalah berupa laporan penelitian dalam bentuk jurnal.

\section{ANALISA DAN PERANCANGAN}

\section{D.1. Sistem Lama}

Berdasarkan data dari Disdukcapil Kabupaten Kampar Provinsi Riau, alur proses pembuatan akta adalah Pemohon membawa berkas persyaratan dan menyerahkan ke petugas pendaftaran akta, selanjutnya Berkas persyaratan di verifikasi oleh verikator, penandatangani buku register akta oleh pelapor dan pegawai, selanjutnya penginputan data dan pencetakan dokumen oleh operator/pegawai, setelah dicetak masuk ke tahap pengesahan dan paraf oleh Kabid Capil, setelah itu dokumen akta di tandatangani oleh kepala dinas, penomoran buku register akta oleh pegawai, tahap selanjutnya pengecapan dan pengarsipan oleh pegawai, penyerahan dokumen akta kepada pemohon oleh pegawai.

\section{D.2. Sistem Usulan}

Alur sistem baru yang diusulkan yaitu pemohon melakukan pendaftaran akta kependudukan melalui sistem, dengan menginputkan data yang diperlukan dan mengupload berkas persyaratan yang berformat gambar. lalu mencetak bukti pendaftaran. Selanjutnya validator melakukan pengecekan terhadap data dan berkas yang telah diinputkan oleh pemohon. Setelah itu dokumen akta kependudukan akan dicetak oleh operator capil yang kemudian di teruskan ke Kabid Capil dan kepala dinas untuk ditandatangani. Kemudian validator akan memberikan informasi kepada user jika dokumen akta kependudukan telah selesai melalui sistem. Pemohon mendatangi kantor Disdukcapil untuk mengambil akta dan melakukan validasi berkas kepada Validator.

\section{D.3. Deskripsi Aktor}

Aktor yang terlibat pada sistem berjumlah 4 aktor yakni Administrator, Pemohon, Validator, dan Kabid Capil. Tabel 1 merupakan tabel deskripsi aktor pengguna sistem.

Tabel 1. Deskripsi Aktor Pengguna Sistem

\begin{tabular}{|c|c|c|c|}
\hline No & Aktor & Synonym & Keterangan \\
\hline 1 & Administrator & Administrator & $\begin{array}{l}\text { Pihak yang } \\
\text { berhak } \\
\text { menggunakan } \\
\text { sistem dan } \\
\text { bertugas } \\
\text { mengelola user } \\
\text { serta mengelola } \\
\text { data penduduk, } \\
\text { dan password } \\
\text { pada sistem. }\end{array}$ \\
\hline 2 & Pemohon & Pemohon & $\begin{array}{l}\text { Pihak yang } \\
\text { menggunakan } \\
\text { sistem untuk } \\
\text { melihat } \\
\text { informasi } \\
\text { persyaratan, } \\
\text { melakukan } \\
\text { pendaftaran, } \\
\text { meng-upload } \\
\text { berkas } \\
\text { persyaratan, } \\
\text { mencetak bukti } \\
\text { pendaftaran, dan } \\
\text { melihat status } \\
\text { akta. }\end{array}$ \\
\hline 3 & Validator & Validator & $\begin{array}{l}\text { Pihak yang } \\
\text { menggunakan } \\
\text { sistem dan } \\
\text { bertugas untuk } \\
\text { melakukan } \\
\text { verifikasi dan } \\
\text { validasi } \\
\text { permohonan } \\
\text { akta } \\
\text { kependudukan } \\
\text { dan mengelola } \\
\text { informasi } \\
\text { persyaratan } \\
\text { serta melihat } \\
\text { laporan } \\
\text { penyerahan. }\end{array}$ \\
\hline 4 & Kabid Capil & $\begin{array}{l}\text { Kepala } \\
\text { Bidang } \\
\text { Catatan Sipil }\end{array}$ & $\begin{array}{l}\text { Pihak yang } \\
\text { menggunakan } \\
\text { sistem untuk } \\
\text { melihat data dan } \\
\text { grafik } \\
\text { permohonan. }\end{array}$ \\
\hline
\end{tabular}

\section{D.4. Perancangan Sistem}

\section{D.4.1. Use Case Diagram}

Use case diagram pada sistem informasi akta kependudukan ini dapat dilihat pada Gambar 3 dengan deskripsi 4 aktor seperti yang telah tertera pada Tabel 1. Diagram inilah yang mempermudah dalam proses deploy system agar sesuai seperti kondisi yang dibutuhkan pada tempat studi kasus. Ada beberapa kasus pengguna yang terlibat seperti Pemohon dapat melakukan pendaftaran, melihat informasi persyaratan, dan status akta. Sedangkan Administrator dapat melakukan kelola akun, user, 
dan data penduduk. Sementara Validator dapat mengelola informasi persyaratan, validasi dan verifikasi pemohon, serta mengelola laporan. Sedangkan untuk Kabid Capil hanya dapat mengelola akun pribadinya dan melihat grafik serta laporan.

\section{D.4.2. Class Diagram}

Class diagram merupakan deskripsi lengkap yang ditangani oleh sistem, dimana masing-masing class telah dilengkapi dengan atribut dan operasioperasi yang diperlukan. Untuk melihat relasi antar tabel beserta atribut-atributnya, dapat dilihat pada Gambar 4 yang digunakan sebagai acuan dalam membangun database sistem pada penelitian ini.

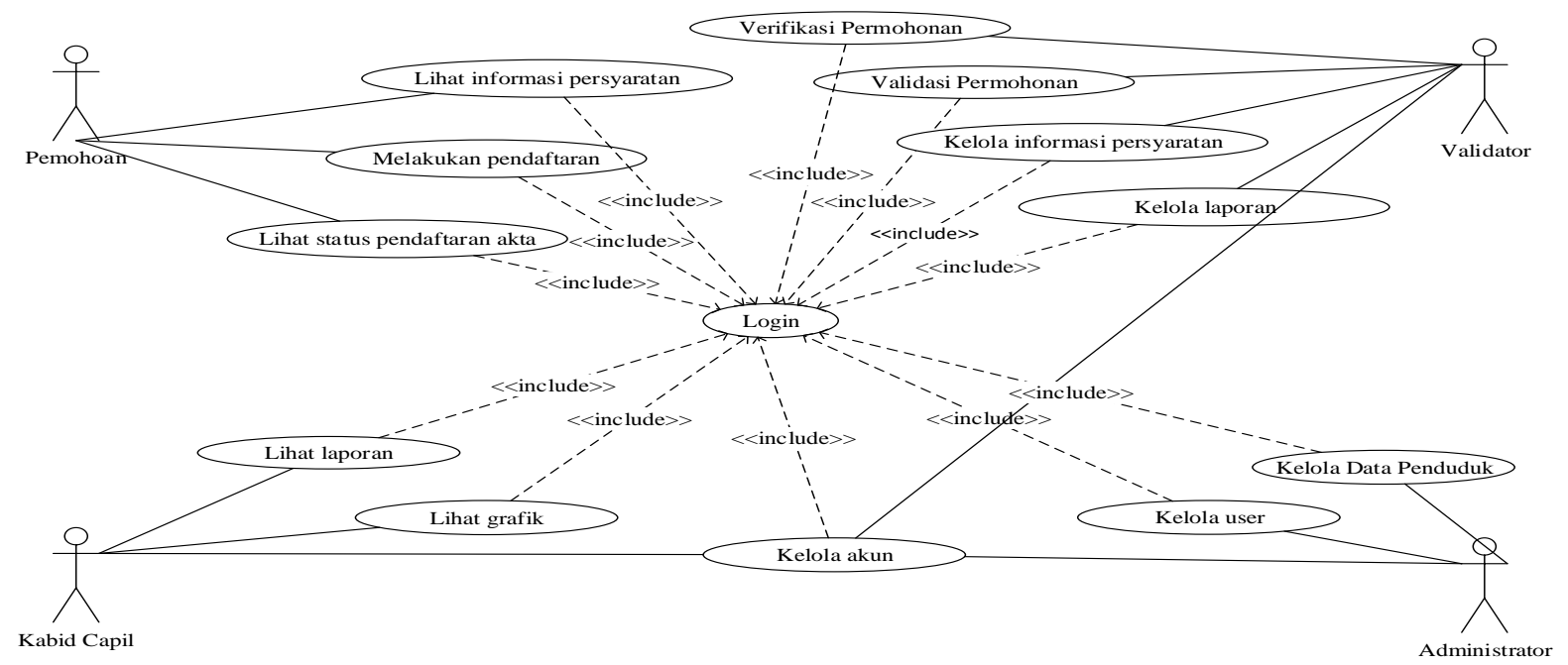

Gambar 3. Use Case Diagram

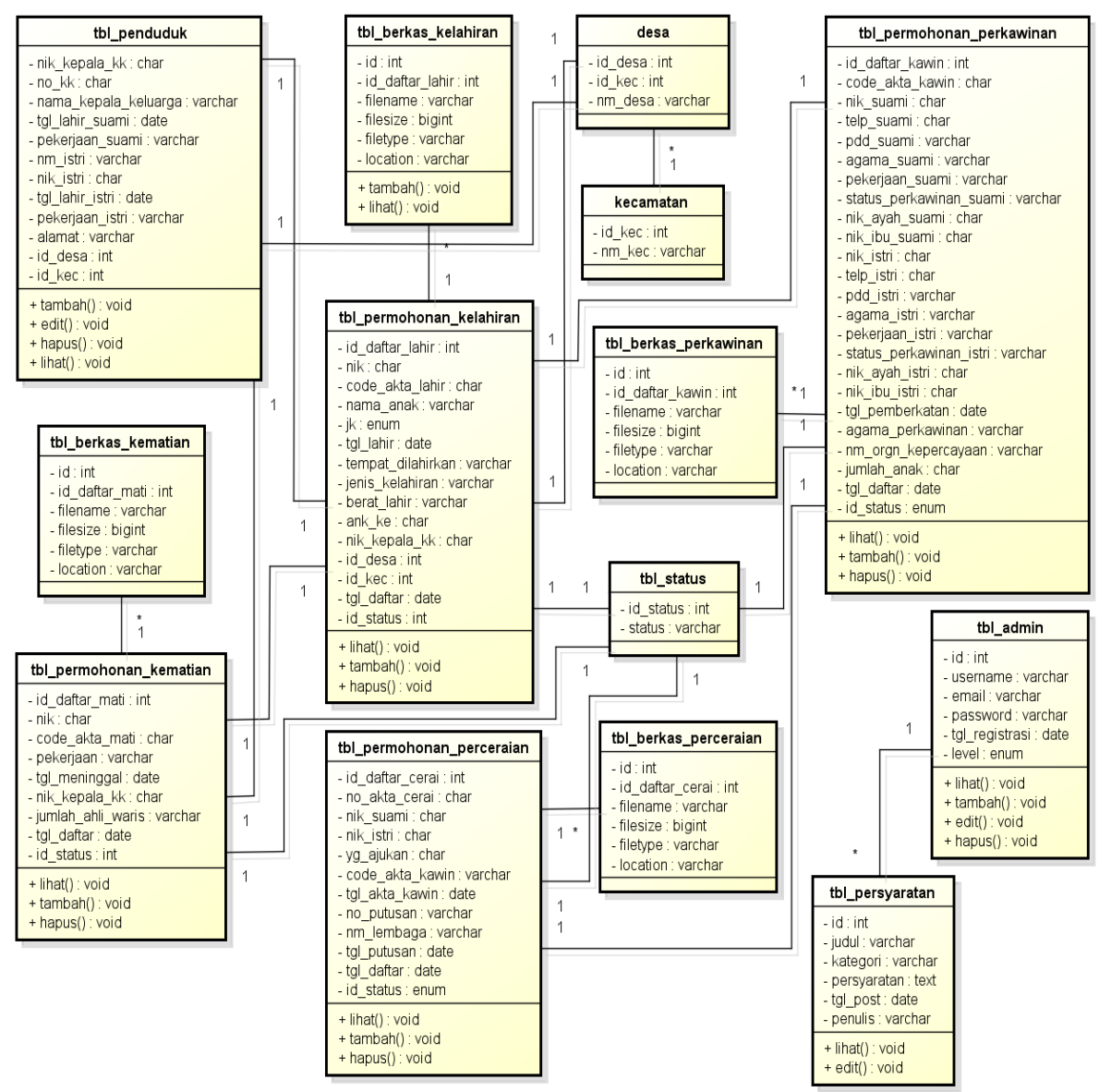

D.4.3. Struktur Menu

Gambar 4. Class Diagram
Struktur menu dibuat sebagai gambaran mengenai skema sistem yang akan dirancang. 
Gambar 5, 6, 7, dan 8 merupakan struktur menu perancangan sistem informasi akta kependudukan berbasis web pada Dinas Kependudukan dan Pencatatan Sipil Kabupaten Kampar untuk 4 aktor pengguna sistem.
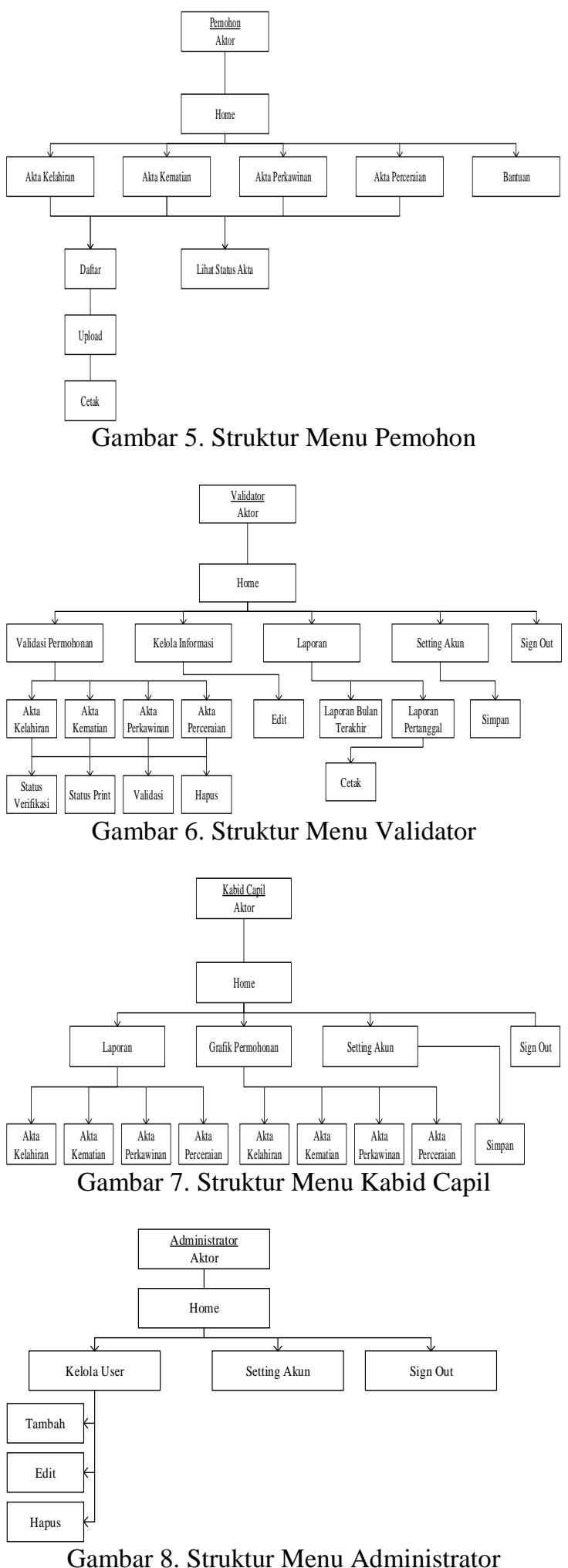

\section{E. HASIL IMPLEMENTASI DAN PENGUJIAN}

\section{E.1. Lingkungan Implementasi}

1) Hardware

Tabel 2. Perangkat Keras Membangun Sistem

\begin{tabular}{lll}
\hline No. & Nama Perangkat & Spesifikasi Perangkat \\
\hline 1. & Prosessor & Intel(R) Core(TM)2 Duo \\
2. & RAM 2.26GHz. \\
3. & Vidio Graphics & I GB \\
& Array (VGA) & Chipset Family 829 MB \\
4. & Hardisk & $320 \mathrm{~GB}$ \\
5. & Monitor & Display 14 inc \\
6. & Keyboard + Mouse & \\
\hline
\end{tabular}

2) Software

Tabel 3. Perangkat lunak Membangun Sistem

\begin{tabular}{lll}
\hline No. & Perangkat Lunak & \multicolumn{1}{c}{ Spesifikasi } \\
\hline 1. & Web Browser & $\begin{array}{l}\text { Google Chrome Version } \\
\text { 55.0.2883.87 m (64-bit) }\end{array}$ \\
2. & PHP & PHP Version 5.6.15 \\
3. & MySQL Server & \\
4. & Bootstrap & Bootstrap 3.3.6 \\
5. & Sublime Text 2 & Version 2.0.2, Build 2221 \\
6. & Adobe Photoshop & CS5 \\
7. & Visio 2013 & Visio @ 2013 \\
& & $(15.0 .4420 .1017)$ 32-bit \\
\hline
\end{tabular}

\section{E.2. Hasil Implementasi}

Gambar 9 Merupakan halaman awal ketika pemohon membuka sistem. Pada halaman ini pemohon memilih akta apa yang akan dibuat. Adapun menu akta yang dapat dipilih adalah akta kelahiran, akta kematian, akta nikah, dan akta perceraian. Setelah memilih salah satu dari menu akta tersebut, barulah pengguna dapat melakukan proses login berdasarkan identitas kependudukan seperti yang terdapat pada Gambar 10.
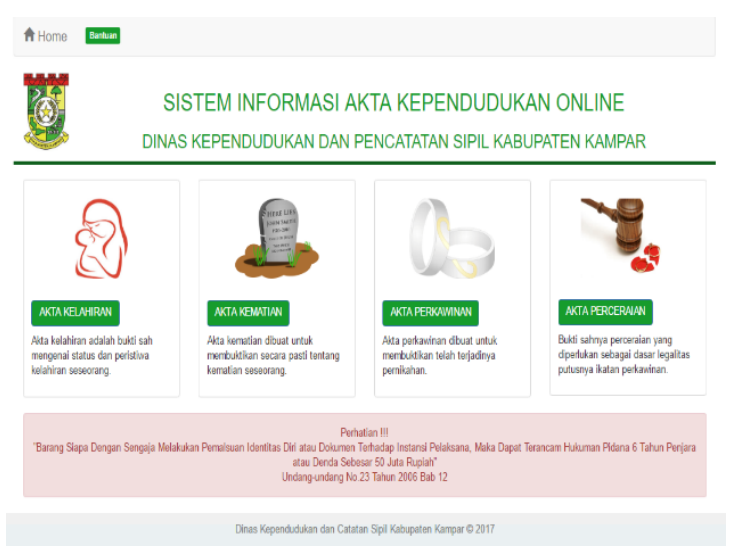

Gambar 9. Halaman Home Pemohoan

Gambar 10 merupakan halaman daftar setelah pemohon memilih jenis akta pada halaman awal sistem. Pada halaman ini ditampilkan persyaratan pembuatan akta kependudukan. 


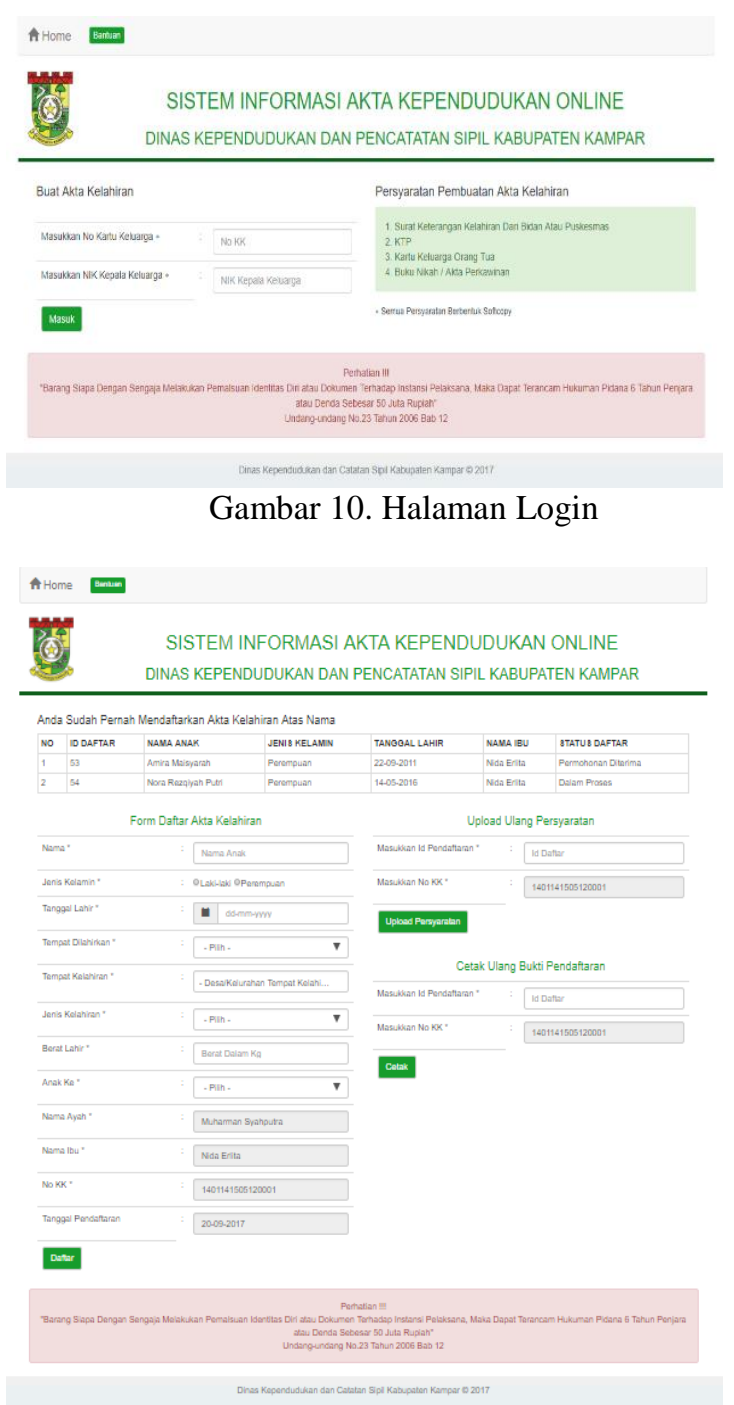

Gambar 11. Halaman Form Pendaftaran Kelahiran

Gambar 11 merupakan halaman salah satu form pendaftaran pengguna. Pada halaman ini pengguna dapat melakukan pendaftaran setelah memilih salah satu menu utama Pemohon seperti pada Gambar 10. Pada sistem ini, pemohon juga dapat meng-upload berkas persyaratan setelah mengisi form pendaftaran.

Setelah pemohon melakukan pendaftaran, selanjutnya sistem menyediakan halaman bukti pendaftaran. Salah satu contoh bukti pendaftaran yang merupakan hasil dari proses pendaftaran dapat dilihat pada Gambar 12.

Setelah pemohon berhasil melakukan proses pendaftaran dan melahirkan bukti pendaftaran, hasil proses tersebut akan dapat dilihat oleh Validator untuk memverifikasi apakah data yang telah diinput oleh pemohon sudah valid atau atau belum beserta lampiran berkas yang telah di-upload. Setelah proses verifikasi ini dilakukan, barulah pihak Disdukcapil menindaklanjuti maksud dari pemohon pada tahapan berikutnya. Untuk melihat halaman Validator melakukan verifikasi dapat dilihat pada Gambar 13 dan Gambar 14.

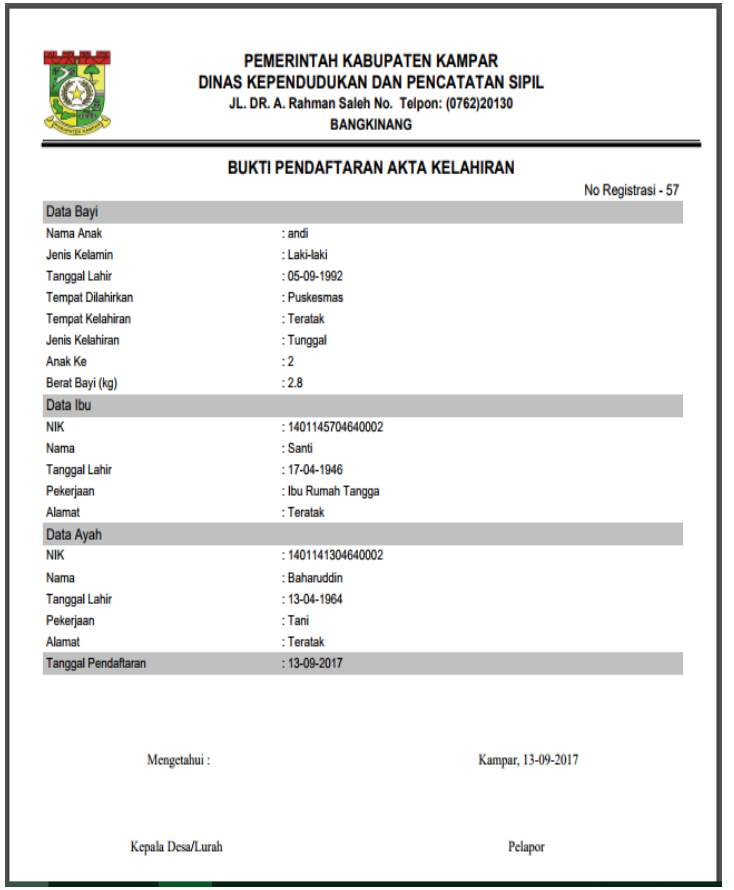

Gambar 12. Bukti Pendaftaran Akta Kelahiran

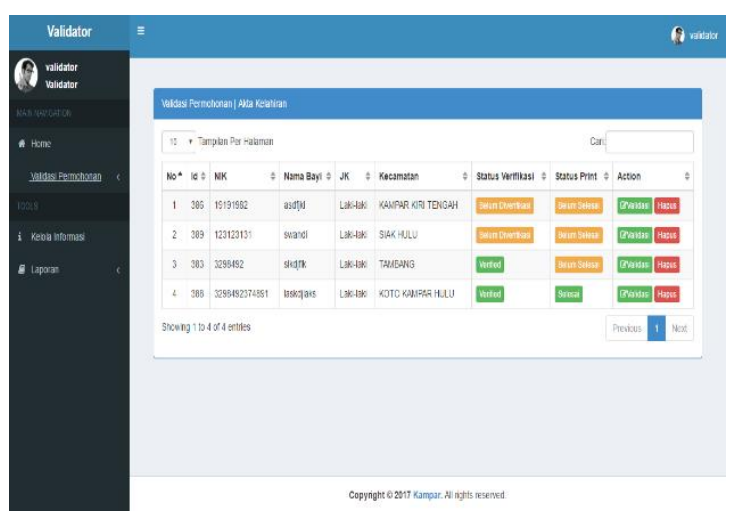

Gambar 13. Halaman Permohonan Masuk

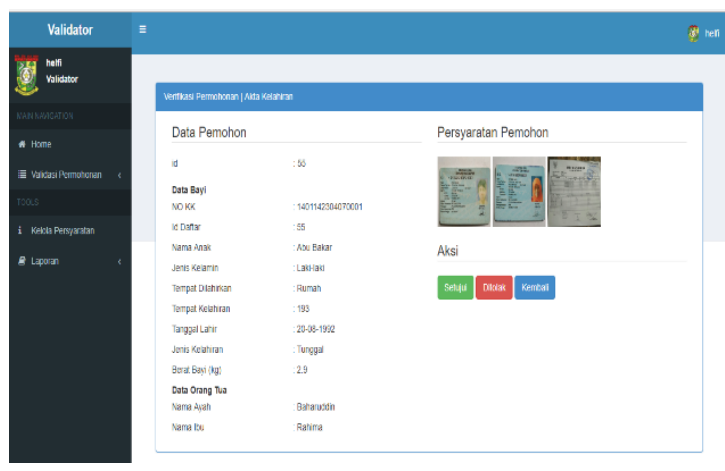

Gambar 14. Halaman Verifikasi

Gambar 15 merupakan halaman laporan Kabid Capil yang berupa tabel jumlah permohonan setiap bulan berdasarkan kecamatan. Selain itu, Kabid Capil juga dapat melihat informasi mengenai pemohon dalam bentuk grafik seperti yang tertera pada Gambar 16. 


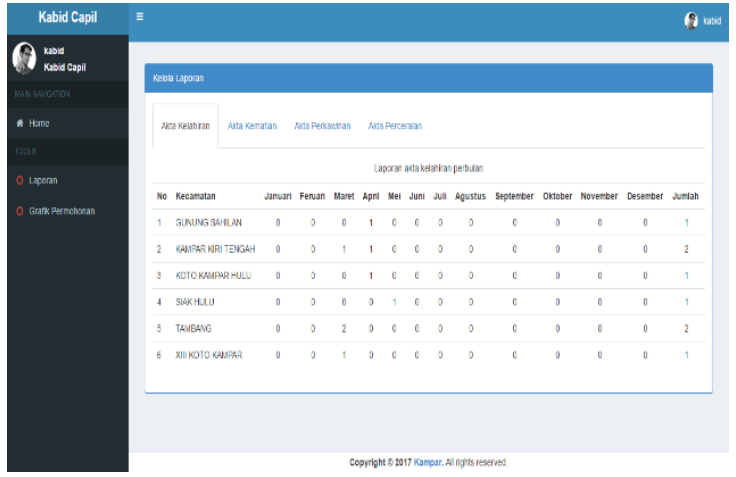

Gambar 15. Halaman Laporan Kabid Capil

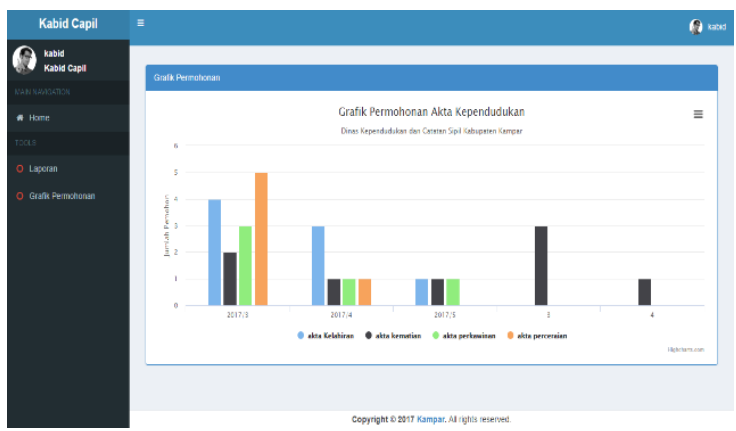

Gambar 16. Grafik Permohonan

\section{E.3. Hasil Pengujian}

Hasil pengujian User Acceptance Test terhadap sistem informasi akta kependudukan berbasis web yang dilakukan oleh lima orang yaitu Kabid Capil, Kasi bagian akta kelahiran dan kematian dan 3 orang masyarakat Kabupaten Kampar menunjukkan tingkat penerimaan yang sangat baik, yaitu $100 \%$. Detail hasil pengujian UAT dapat dilihat pada Tabel 4 .

Tabel 4. Hasil Pengujian User Acceptance Test

\begin{tabular}{lr}
\hline Penguji & Tingkat Penerimaan \\
\hline Penguji 1 & $100 \%$ \\
Penguji 2 & $100 \%$ \\
Penguji 3 & $100 \%$ \\
Penguji 4 & $100 \%$ \\
Penguji 5 & $100 \%$ \\
Rata-rata & $\mathbf{1 0 0 \%}$ \\
\hline
\end{tabular}

\section{F. KESIMPULAN}

Berdasarkan tahapan-tahapan penelitian yang telah dilalui maka dapat disimpulkan bahwa sistem yang telah dibangun dapat diterima dengan sangat baik oleh pihak Dinas Kependudukan dan Pencatatan Sipil Kabupaten Kampar Provinsi Riau. Sistem yang telah dibangun dapat direkomendasikan untuk digunakan sebagai media baru yang dapat meningkatkan kinerja serta dapat membantu masyarakat dalam kepengurusan akte pada Dinas Kependudukan dan Pencatatan Sipil Kabupaten Kampar Provinsi Riau.

\section{REFERENSI}

[1] Dinas Kabupaten Kampar, Riau, Indonesia. http://www.kamparkab.go.id. Diakses pada 20 Februari 2017.

[2] Badan Pusat Statistik Kabupaten Kampar, 2016. Kabupaten Kampar Dalam Angka 2016. ISSN: 0215-3858.

[3] Pressman, R.S. (2010), Software Engineering: a practitioner's approach, McGraw-Hill, New York, 68.

[4] Sommerville, Ian. Software Engineering (Rekayasa Perangkat Lunak). Erlangga, Jakarta, 2011.

[5] Suripto, Muhammad Agus dan Ramadian Agus Triyono. Pembangunan Sistem Informasi Akta Kelahiran Dinas Kependudukan dan Catatan Sipil Sragen. Indonesian Journal on Networking and Security (IJNS) - Volume 3 No 3, ISSN: 2302-5700, Juli 2014.

[6] Suarti, Syilvia Nurhabibah dan Sujianto. Reformasi Birokrasi Pengurusan Akta Kelahiran di Dinas Kependudukan dan Catatan Sipil Kabupaten Kampar, Jom FISIP Volume 1 No.2 Oktober 2014.

[7] Eddy, O.S Hiariej. Teori dan Hukum Pembuktian. Erlangga, Jakarta 2012.

[8] Nugroho, Adi. Analisis dan Perancangan Sistem Informasi dengan Metodologi Berorientasi Objek. Informatika, Bandung 2012.

[9] Satzinger JS, Jackson RB, Burd SD. 2010. Systems Analysis and Design In a Changing World. Fifth Edition. Course Technology. Cengage Learning. Boston-USA.

[10] [KBBI] Kamus Besar Bahasa Indonesia. 2016. Badan Pengembangan dan Pembinaan Bahasa, Kementerian Pendidikan dan Kebudayaan Republik Indonesia (Kemendikbud) https://kbbi.kemdikbud.go.id /entri/akta. Diakses pada tanggal 22 Februari 2017, pukul 21:00 WIB.

[11] Ahsyar, Tengku Khairil, dan Abd Rahman. "Sistem Monitoring Piutang Dan Inventori Barang Di PT. Anugrah Citra Pestisindo." Jurnal Ilmiah Rekayasa dan Manajemen Sistem Informasi 4.2 (2018): 142-149.

[12] Hairiyadi, Andri, and Tengku Khairil Ahsyar. "Sistem Electronic-Human Resource Management (e-HRM) Menggunakan Metode Rapid Application Development (Studi Kasus: PT. Andesta Mandiri Indonesia)." Jurnal Ilmiah Rekayasa dan Manajemen Sistem Informasi 5.2 (2019): 126-135. 